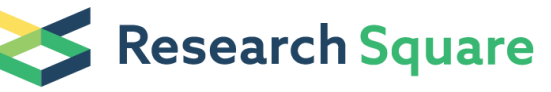

\section{Beneficial Effects of Decreased Meal Frequency on Nutrient Utilization, Secretion of Luteinizing Hormone and Ovarian Follicular Development in Gilts}

\author{
Lun Hua \\ Sichuan Agricultural University \\ Lianpeng Zhao \\ Sichuan Agricultural University \\ Zhengyu Mao \\ Sichuan Agricultural University \\ Wentao Li \\ Sichuan Agricultural University \\ Jing Li \\ Sichuan Agricultural University
}

Xuemei Jiang

Sichuan Agricultural University

Lianqiang Che

Sichuan Agricultural University

Shenyu Xu

Sichuan Agricultural University

Yan Lin

Sichuan Agricultural University

Zhengfeng Fang

Sichuan Agricultural University

Bin Feng

Sichuan Agricultural University

\section{Yong Zhuo}

Sichuan Agricultural University

DeWu ( $\nabla$ wude@sicau.edu.cn )

Animal Nutrition Institute https://orcid.org/0000-0003-1873-9914

\section{Research}

Keywords: Gilts, Luteinizing hormone, Meal frequency, Nutrient utilization, Ovarian follicular development 
Posted Date: October 9th, 2020

DOI: https://doi.org/10.21203/rs.3.rs-86939/v1

License: (c) (i) This work is licensed under a Creative Commons Attribution 4.0 International License. Read Full License

Version of Record: A version of this preprint was published at Journal of Animal Science and Biotechnology on April 6th, 2021. See the published version at https://doi.org/10.1186/s40104-02100564-4. 


\section{Abstract}

Background: The replacement gilts are typically fed ad libitum, whereas emerging evidence in human and rodent studies revealed that time-restricted access to food had health benefits. The objective of this study was to investigate the effect of meal frequency on metabolic status and ovarian follicular development in gilts.

Methods: A total of 36 gilts (Landrace $\times$ Yorkshire) at age of $150( \pm 3) \mathrm{d}$ and bodyweight at $77.6( \pm 3.8) \mathrm{kg}$ were randomly allocated into one of three meal frequencies $(n=12)$ to feed one meal $(T 1)$; two meals (T2), or six meals per day (T6) for a consecutive 14 weeks. The effect of meal frequency on growth preference, nutrient utilization, gut microbial metabolite short-chain fatty acids production at a 3-h interval, dynamics of metabolic status after a meal test, reproductive hormone secretions, and ovarian follicular development were measured in gilts.

Results: Gilts in T1 group had greater average daily gain $(+48 \mathrm{~g} / \mathrm{d}, P<0.05)$ and bodyweight $(+4.9 \mathrm{~kg}, P<$ $0.05)$ than T6 gilts. The apparent digestibilities of dry matter, crude protein, ether extract, ash and gross energy were not affected by meal frequency, except for a greater NDF digestibility in T1 gilts than T6 gilts $(P<0.05)$. Nitrogen balance trail reveal that the T1 gilts had lower urine excretion of nitrogen $(-8.17 \mathrm{~g} / \mathrm{d}, P$ $<0.05)$ and had a greater nitrogen retention $(+9.81 \mathrm{~g} / \mathrm{d}, P<0.05)$, resulting in greater nitrogen utilization compared with T6 gilts. The time-course dynamics of glucose, a-amino nitrogen, urea, lactate, and insulin levels in serum revealed a greater utilization of nutrients after a meal test in T1 gilts than T2 or T6 gilts. The T1 gilts showed greater acetate content in feces compared with the other two groups $(P<0.05)$. The age, bodyweight and backfat thickness at first puberty of gilts were not affected by meal frequency, but gilts in T1 group had greater serum levels of luteinizing hormone and 17ß-estradiol, a larger number of growing follicles and corpora lutea, and higher mRNA expression levels of genes related to follicular development on the $18^{\text {th }}$ day of the $3^{\text {rd }}$ estrus cycle.

Conclusions: The current findings revealed unexpected benefits of meal frequency at one meal per day on the nutrient utilizations and reproductive function for replacement gilts, thus providing new insights into the nutritional strategy for replacement gilts, as well as the dietary pattern for other mammals, such as human.

\section{Background}

The management of replacement gilts is critical for the modern swine production since $40-50 \%$ of culling sows have to be replaced by the gilts [1]. The successful replacement gilts not only require a sound growth performance, but also a suitable activation of hypothalamic-pituitary-gonadal (HPG) axis which is characterized by the pulsatile release of reproductive hormones, such as gonadotropin releasing-hormone $(\mathrm{GnRH})$, follicle-stimulating hormone $(\mathrm{FSH})$, luteinizing hormone $(\mathrm{LH})$, and estradiol $\left(\mathrm{E}_{2}\right)[1,2]$. Those reproductive hormones in turn, affect the pubertal onset and maintain the estrous cycle, and disruption or 
perturbation of HPG axis leads to hypogonadotropic hypogonadisms resulting in subfertility and even infertility for female.

Interestingly, the activation of HPG axis only occurs under a nutrition favorable situation, and several nutrition-related metabolites or metabolic hormones was observed to influence the secretion of gonadotropins [3-5], suggesting the opportunity to control the HPG axis of gilts by nutritional strategies. Currently, the replacement gilts are typically fed ad libitum, which encourages extending the period of daily nutrient intake and thereby shortening the fasting period. However, growing evidence revealed that this free eating pattern has been associated with an increased prevalence of metabolic diseases in human and rodents [6-8], and on the contrary, studies of laboratory animals and human have shown that decreased meal frequency (MF) can increase insulin sensitivity and thereby reduce the obesity related metabolic diseases, and even extend lifespan [7-9]. Furthermore, decreased MF change the diurnal dynamics and even shift the gut microbiome which had benefits for metabolic health $[10,11]$. Decreasing the MF was able to alter the nutrient utilization, and inflammation status in growing pigs $[9,12]$. The above evidence indicated that meal frequency may play a critical role on the female reproductive system since a body of experimental evidence have indicated a fundamental link between metabolic status and normal estrus cycle. However, there is currently no clear evidence of the effect of MF on the HPG axis in gilts. Therefore, in this present study, the objective was to investigate the effect of MF on gut microbial metabolite short-chain fatty acids (SCFAs) production, metabolic status, reproductive hormone secretion, and ovarian follicular development in gilts.

\section{Materials And Methods}

All experimental procedures followed the regulations of the Animal Care and Use Committee of Sichuan Agricultural University (S20174302), and were in accordance with the National Research Council's Guide for the Care and Use of Laboratory Animals.

\section{Animals And Experimental Design}

Thirty-six Landrace $\times$ Yorkshire crossbred gilts of initially similar body weight $(77.6 \pm 3.8 \mathrm{~kg})$ and age (150 $\pm 3 \mathrm{~d}$ ) were fed the same corn-soybean meal based diet (Table 1) with one of three meal frequencies $(\mathrm{n}=$ 12): one meal per day (T1); two meals per day (T2), and six meals per day (T6) for a consecutive 14 weeks. The daily feed allowances were $2.2 \mathrm{~kg}$ from 1 st week to 10 th week, and $2.4 \mathrm{~kg}$ from 11 th week to end of experiment (around the 14th week), respectively. The gilts in the T1 group had access to feed from 08:00 to 11:00; the gilts in the T2 group had access to half of the feed at 08:00-09:30 and from 14:0015:30, respectively; the gilts in the T6 group had access to one-six of feed at 08:00-08:30, 11:00-11:30, 14:00-14:30, 17:00-17:30, 19:00-19:30, and 21:00-21:30, respectively. Water was provided ad libitum. Gilts were housed individually in each pen in an environmentally controlled room with temperature between $18^{\circ} \mathrm{C} 22^{\circ} \mathrm{C}$. 
Table 1

Ingredients and nutrient content of experimental diets

Ingredients

Corn

Soybean meal $(44 \% \mathrm{CP})$

Fish meal $(65 \% \mathrm{CP})$

Soybean oil

Wheat bran

Corn starch

L-Lysine sulfate, $98.5 \%$

DL-Methionine, $99.0 \%$

Limestone

Calcium phosphate (dibasic)

Sodium chloride (feed-grade, 99\%)

Choline chloride (50\%)

${ }^{1}$ Premix

Total

${ }^{2}$ Calculated nutrient levels

Digestible energy, $\mathrm{kcal} / \mathrm{kg}$

Crude protein, \%

Calcium, \%

Total phosphorus, \%

STTD phosphorus, \%

SID-Lysine

SID-(Met + Cys) $\mathrm{g} / \mathrm{kg}$

708.38

160.00

30.00

13.00

33.40

27.42

1.20

0.10

6.00

11.00

4.00

1.50

4.00

1000.00

\subsection{8}

15.76

0.67

0.60

0.38

0.80

0.45

${ }^{1}$ Provided per $\mathrm{kg}$ of diet: $\mathrm{Cu}, 20 \mathrm{mg}$ as copper sulfate; $\mathrm{Fe}, 80 \mathrm{mg}$ as ferrous sulfate; $\mathrm{Zn}, 100 \mathrm{mg}$ as zinc sulfate; Mn, $25 \mathrm{mg}$ as manganese sulfate; Se, $0.15 \mathrm{mg}$ as sodium selenite; l, $0.14 \mathrm{mg}$ as potassium iodide, vitamin $\mathrm{A}, 4000 \mathrm{IU}$; vitamin $\mathrm{D}_{3}, 800 \mathrm{lU}$; vitamin $\mathrm{E}, 441 \mathrm{IU}$; menadione, $0.5 \mathrm{mg}$; thiamine, $1.0 \mathrm{mg}$; riboflavin, $3.75 \mathrm{mg}$; vitamin $\mathrm{B}_{6}, 1.0 \mathrm{mg}$; vitamin $\mathrm{B}_{12}, 15 \mu \mathrm{g}$ niacin, $10 \mathrm{mg}$; $\mathrm{D}$-pantothenic acid, $12 \mathrm{mg}$; folic acid, $1.3 \mathrm{mg}$; D-biotin, $200 \mu \mathrm{g}$.

${ }^{2}$ Calculated values based on China Feed Information Database 2013. 
SID-Threonine

0.48

SID-Tryptophan

0.15

${ }^{1}$ Provided per kg of diet: $\mathrm{Cu}, 20 \mathrm{mg}$ as copper sulfate; $\mathrm{Fe}, 80 \mathrm{mg}$ as ferrous sulfate; $\mathrm{Zn}, 100 \mathrm{mg}$ as zinc sulfate; $\mathrm{Mn}, 25 \mathrm{mg}$ as manganese sulfate; Se, $0.15 \mathrm{mg}$ as sodium selenite; l, $0.14 \mathrm{mg}$ as potassium iodide, vitamin $\mathrm{A}, 4000 \mathrm{IU}$; vitamin $\mathrm{D}_{3}, 800 \mathrm{IU}$; vitamin $\mathrm{E}, 441 \mathrm{IU}$; menadione, $0.5 \mathrm{mg}$; thiamine, $1.0 \mathrm{mg}$; riboflavin, $3.75 \mathrm{mg}$; vitamin $\mathrm{B}_{6}, 1.0 \mathrm{mg}$; vitamin $\mathrm{B}_{12}, 15 \mu \mathrm{g}$ niacin, $10 \mathrm{mg}$; D-pantothenic acid, $12 \mathrm{mg}$; folic acid, $1.3 \mathrm{mg}$; D-biotin, $200 \mu \mathrm{g}$.

${ }^{2}$ Calculated values based on China Feed Information Database 2013.

\section{Measurement of growth traits}

The fasted body weight was determined every two weeks in the morning before the first meal. Back-fat thickness was measured $65 \mathrm{~mm}$ on both sides of the dorsal mid-line at the last rib using an ultrasound scanner using a Lean Meater (Renco-Lean Meater, Minneapolis, MN, USA). Both side measurements were averaged to obtain a final value.

\section{Estrous detection}

Estrous was not induced by exogenous hormone administration for these gilts. The onset of the first observed estrous was carefully checked to ensure that puberty was detected. All gilts were exposed to mature boars with fence line to encourage pubertal estrous. To maintain a similar criterion of detection, estrous onset was detected by only one experienced stockperson based on behavioral and vulvar characteristics. The appearance of a pink vulva and vaginal orifice mucous, and standing still under applied back pressure (standing heat) was used as an important behavioral criterion to establish onset of estrous. Age, body weight and back-fat thickness at puberty were recorded on the day of estrous.

\section{Nutrient digestibility and nitrogen balance determination}

Twenty-four healthy gilts (eight gilts per group) were randomly chosen to be used to detect the nutrient digestibility and in a nitrogen balance trial after 12 weeks' treatments. During this period, feeding schedules were kept the same as before. The digestibilities of dry matter (DM), ether extract (EE), crude protein (CP), neutral detergent fiber (NDF), Gross energy, and nitrogen balance were measured. Gilts were individually housed in stainless-steel metabolism cages equipped with waterers and feeders and feeding schedules were kept the same as before. There were a 4-day adaptation period and a 5-day sample collection period. During the first day and the last day of nitrogen balance trail, $5 \mathrm{~g}$ of chromic oxide was added to $100 \mathrm{~g}$ of the basal diet on the morning meal as a color marker to indicate the start or the end of fecal sample collection when the green color appeared in feces. The freshly collected feces were immediately added with several drops of methylbenzene to prevent fermentation. The collected fecal samples for every $24 \mathrm{~h}$ were pooled together, weighed, and placed on ice, and $1 \mathrm{~mL} \mathrm{HCl} \mathrm{(10 \% )} \mathrm{was} \mathrm{added}$ to very $10 \mathrm{~g}$ of feces to prevent nitrogen loss. The urine of each gilts was collected to a plastic container 
and measured every $24 \mathrm{~h}$ was from 08:00 at the starting day to 08:00 of the end days during nitrogen balance trial. Several drops of $\mathrm{H}_{2} \mathrm{SO}_{4}(98 \%)$ was added to the urine to maintain a pH less than 3.0. and a representative urine subsample (5\%) were obtained to store at $4{ }^{\circ} \mathrm{C}$ until analysis. The collected feces and urine samples were pooled together at the end of each nitrogen balance trial. Feces were dried in a forcedraft oven $\left(65^{\circ} \mathrm{C}\right)$ for $2 \mathrm{~d}$ and then weighed. Dried feces were ground through a $1 \mathrm{~mm}$ screen and frozen until subsequent detections of DM, EE, energy, NDF and nitrogen content. DM, ether extract (EE), $C P$, and NDF was determined using the AOAC procedure (2000). Nitrogen content of diets, urine and feces was determined by the combustion method using a Leco TruSpec analyzer. Gross energy of feed and feces was determined by a Parr 6400 bomb calorimetry (Parr Instrument Co., Moline, IL, USA).

\section{Sample collections and analysis}

Fresh feces were collected directly by massaging the rectum of each gilts after 13 weeks' treatment every 3 hours of a day. Then, freshly collected samples were transported in solidified carbon dioxide and then stored at $-80^{\circ} \mathrm{C}$ until analysis. The SCFAs concentrations of feces were analyzed through a gas chromatographic method as previously described [13]. Briefly, $0.7 \mathrm{~g}$ of fecal sample was suspended in $1.5 \mathrm{~mL}$ of distilled water, mixed and placed for $30 \mathrm{~min}$. Afterwards, the samples were centrifuged $(15,000 \mathrm{~g})$ at $4^{\circ} \mathrm{C}$ for $15 \mathrm{~min}$. One $\mathrm{mL}$ supernatant was transferred and mixed with $0.2 \mathrm{~mL}$ metaphosphoric acid $(25 \%, \mathrm{w} / \mathrm{v})$ and $23.3 \mu \mathrm{L}$ crotonic acid $(210 \mathrm{mmol} / \mathrm{L}$, internal standard). After mixing, they were incubated at $4^{\circ} \mathrm{C}$ for $30 \mathrm{~min}$, and centrifuged at $15,000 \mathrm{~g}$ for $10 \mathrm{~min}$. After centrifuged, $0.3 \mathrm{~mL}$ liquid was transferred and mixed with $0.9 \mathrm{ml}$ chromatographic methanol (1:3 dilution), and 10,000 $\mathrm{g}$ was centrifuged for $5 \mathrm{~min}$. Aliquot of the supernatant $(1 \mu \mathrm{L})$ was analyzed using a gas chromatography (Varian CP-3800 GC, USA).

For meal test, the first blood sampling occurred at $07: 50$ and was then followed by a test meal $(800 \mathrm{~g}$ of diets in each group). After consuming the morning meal completely ( $0 \mathrm{~min})$, the subsequent blood samplings were collected every $10 \mathrm{~min}$ in the first hour, every $15 \mathrm{~min}$ in the 2 nd hour and every $30 \mathrm{~min}$ in the $3 \mathrm{rd}$ hour. The blood samples were centrifuged at $2,500 \mathrm{~g}$ at $4{ }^{\circ} \mathrm{C}$ for $30 \mathrm{~min}$ to collect serum, which was stored at $-20^{\circ} \mathrm{C}$ for future analysis. Serum glucose, lactate, and urea levels were measured on an automatic biochemical analyzer (7020; Hitachi, Tokyo, Japan) with their respective commercial analysis kits (Beijing Strong Biotechnologies, Beijing, China), according to the manufacturer's instructions. Serum a-amino nitrogen concentration was measured using a colorimetric method. Serum insulin levels were measured with commercial ELISA kits (KE10032, Proteintech Group, Rosemont, PA, USA), according to the manufacturer's instructions.

Additional blood samples were collected at the 18th day of the third estrous cycle every 30 min for 4 hours. Serum LH (B162447) and FSH (B162448) concentrations were measured with commercial ELISA kits, according to the manufacturer's instructions (BIM, San Francisco, USA).

On the 19th day of the 3rd estrous cycle, blood samples were collected for measuring serum 17 $\beta$-estradiol levels (KGE014, R\&D Systems; Bio-Techne, Minneapolis, MN, USA), and five gilts from each group were randomly selected to collect bilateral ovaries. Ovaries were washed with ice-cooled phosphate buffer 
saline (PBS) three times. The cumulus-oocytes complex (COC) were obtained from antral follicles with diameter larger than $3 \mathrm{~mm}$ as previously described [13], and were snap-frozen and stored at $-80{ }^{\circ} \mathrm{C}$. The right ovary was fixed in $4 \%$ paraformaldehyde $(100 \mathrm{mmol} / \mathrm{L}$ phosphate buffer, $\mathrm{pH}=7.4)$.

\section{Tissue histology and follicle counts}

Ovaries were fixed with $4 \%$ paraformaldehyde in PBS, and then dehydrated, embedded in paraffin, sectioned (5- $\mu \mathrm{m}$ thickness) and stained with hematoxylin and eosin (HE). The HE stained sections were examined under microscopy (Nikon 80i). The quantification of ovarian follicles, including primordial follicle, primary follicle, secondary follicle, and antral follicle, was performed as previously described [14]. In order to prevent repeated counting of follicle, six sections with at least $500 \mu \mathrm{m}$-interval were stained, and only those with a visible nucleus in each oocyte were counted. For primordial, primary, and secondary follicles, only those with visible nucleus were counted, and those without nucleus were not counted. For the antral follicles with diameter below $1 \mathrm{~mm}$ that are not easy to be found in ovarian sections, those with visible oocytes were count even they do not have a visible nucleus. The area of HE stained sections were estimated by the Image Pro Plus for Windows 6.0 (Media Cybernetics, Maryland, MD, USA). The number of follicle at each stage was normalized by the area of HE stained ovarian tissue in the sections and presented as number of follicle per $\mathrm{cm}^{2}$ as previous described [15].

\section{RNA extraction and gene expression analysis}

RNA extraction and real-time PCR were performed as previously reported [16]. Briefly, RNA from ovarian was extracted by Trizol (15596018; Thermo Fisher Scientific) and purified using RNA mini-columns (RR037A; Takara Bio, Kusatsu, Japan). Reverse transcription and SYBR green quantitative PCR (RR820A; Takara Bio) were performed according to the manufacturer protocols. Target primer sequences are shown in Table 2. 
Table 2

Sequence of primers used for qPCR

\begin{tabular}{|c|c|c|}
\hline Genes & Forward & Reverse \\
\hline$\beta-A C T I N$ & GGCCGCACCACTGGCATTGTCAT & AGGTCCAGACGCAGGATGGCG \\
\hline FSHR & TCACAGTCCCTCGGTTCCTT & AGCATCACAGCCTGCTCCA \\
\hline LHCGR & ATGGGGCTCTACCTGCTACTCA & GAGCCACCCTCCAAGCATAA \\
\hline GDF9 & СТСТGССТСТTССТССТССАСТG & GGTGAATGAGTACGGTGCTCTTGG \\
\hline BMP15 & ACCATGCCATCATTCAGAGCCTTG & CGTTGGTCTCAATCAGGAGGATGC \\
\hline CYP11a1 & GGCTCCAGAGGCCATAAAGA & ACTCAAAGGCGAAGCGAAAC \\
\hline STAR & GACTTTGTGAGTGTCGGCTGTA & ATCCCTTGAGGTCAATGCTG \\
\hline $3 \beta-H S D$ & CACTGACCTGGGCTGATGAC & GTGGCGAGAAGCAGACAAGA \\
\hline CYP17a1 & TCCAAGCCAAGACGAAC & TTTACCACAGAGGCAGAAG \\
\hline CYP19a1 & GCTGCTCATTGGCTTAC & TCCACCTATCCAGACCC \\
\hline \multicolumn{3}{|c|}{$\begin{array}{l}\text { Abbreviations: FSHR, follicle-stimulating hormone receptor; } L H C G R \text {, luteinizing hormone/chorionic } \\
\text { gonadotropin receptor; GDF9, Growth differentiation factor } 9 \text {; BMP15, bone morphogenetic protein } 15 \text {; } \\
\text { CYP11a1, cytochrome P450 family } 11 \text { subfamily A member } 1 \text {; STAR, steroidogenic acute regulatory } \\
\text { protein; } 3 \beta H S D, 3 \beta \text {-hydroxysteroid dehydrogenase; CYP17a 1, cytochrome P450 family } 17 \text { subfamily A } \\
\text { member } 1 \text {; CYP19a1, cytochrome P450 family } 19 \text { subfamily A member } 1 \text {. }\end{array}$} \\
\hline
\end{tabular}

\section{Statistical analysis}

Date of area under a curve (AUC) was calculate by Prism 6 software (GraphPad Software, La Jolla, CA, USA). Data were presented as mean \pm SEM and analyzed by one-way analysis of variance (ANOVA) with Tukey's test for multiple comparisons to determine differences between each group with Prism 6 software. Serum nutrient and hormone concentrations obtained from the serial serum sampling were analyzed by the MIXED procedure with meal frequency, replicate, a repeated statement for sampling time, and the interaction between meal frequency and time as the main effects (SAS Inst. Inc., Cary, NC, USA). The data on the rate of gilts that reached puberty at $180 \mathrm{~d}, 200 \mathrm{~d}$ and $250 \mathrm{~d}$ were analyzed $\chi 2$ test. Statistical significance was set at $P \otimes 0.05$.

\section{Results}

\section{Effects of meal frequency on grown preference in gilts}

In the present study, all gilts consumed their feed completely at the given time. Thus, all gilts had similar amount of feed every day. As shown in Table 3, the bodyweight at the final of experiment was greater in T1 gilts compared with that in T6 gilts $(+4.9 \mathrm{~kg}, P<0.05)$. The average daily gain of gilts in the T6 group was greater than T1 gilts during weeks $0-2(P<0.05)$. The average daily gain of gilts in the T1 group was 
greater than T6 gilts during weeks $6-8$, and weeks $0-14$ of experiment $(P<0.05)$. Gilts fed one meal a day increased the backfat thickness at the end of week $8(+1.57 \mathrm{~mm}, P<0.05)$, compared with the gilts fed six meals a day. 
Table 3

Effects of meal frequency on growth performance of gilt $1,2,3$

T1

T2

T6

P-value

Body weight $(\mathrm{kg})$

\begin{tabular}{lllll} 
Initial & $77.7 \pm 0.92$ & $77.9 \pm 1.07$ & $77.6 \pm 1.63$ & 0.980 \\
\hline 2nd week & $86.9 \pm 1.19$ & $88.8 \pm 1.22$ & $88.3 \pm 1.67$ & 0.612 \\
\hline 4th week & $100.2 \pm 1.50$ & $101.1 \pm 1.07$ & $100.3 \pm 1.73$ & 0.889 \\
\hline 6th week & $110.1 \pm 1.46$ & $111.3 \pm 1.28$ & $109.7 \pm 1.76$ & 0.735 \\
\hline 8th week & $120.3 \pm 1.35$ & $119.9 \pm 1.59$ & $118.0 \pm 1.91$ & 0.580 \\
\hline 10th week & $128.2 \pm 1.20$ & $127.1 \pm 1.47$ & $124.7 \pm 1.65$ & 0.237 \\
\hline 12th week & $137.5 \pm 1.24$ & $136.0 \pm 1.74$ & $133.0 \pm 1.58$ & 0.132 \\
\hline 14th week & $146.5 \pm 1.43^{\mathrm{a}}$ & $143.9 \pm 1.85^{\mathrm{ab}}$ & $141.6 \pm 1.72^{\mathrm{b}}$ & 0.042 \\
\hline ADG (g/d) & & & & \\
\hline Week 0-2 & $763.9 \pm 34.44^{\mathrm{a}}$ & $901.4 \pm 28.01^{\mathrm{b}}$ & $896.5 \pm 27.32^{\mathrm{b}}$ & 0.004 \\
\hline Week 2-4 & $832.3 \pm 26.18$ & $771.9 \pm 30.23$ & $744.3 \pm 29.75$ & 0.102 \\
\hline Week 4-6 & $703.6 \pm 39.87$ & $728.6 \pm 32.94$ & $673.8 \pm 22.37$ & 0.499 \\
\hline Week 6-8 & $727.4 \pm 42.80^{\mathrm{a}}$ & $611.9 \pm 35.34^{\mathrm{b}}$ & $592.9 \pm 31.77^{\mathrm{b}}$ & 0.031 \\
\hline Week 8-10 & $567.9 \pm 28.73$ & $517.9 \pm 28.58$ & $481.0 \pm 29.96$ & 0.122 \\
\hline Week 10-12 & $662.5 \pm 37.88$ & $631.5 \pm 40.34$ & $594.6 \pm 31.64$ & 0.436 \\
\hline Week 12-14 & $642.9 \pm 78.89$ & $569.6 \pm 64.97$ & $612.5 \pm 29.22$ & 0.700 \\
\hline Week 0-14 & $701.5 \pm 8.73^{\mathrm{a}}$ & $673.5 \pm 13.03^{\mathrm{ab}}$ & $653.4 \pm 8.74^{\mathrm{b}}$ & 0.009 \\
\hline Backfat thickness $(\mathrm{mm})$ & $10.01 \pm 0.41$ & $9.98 \pm 0.31$ & & \\
\hline Initial & $10.45 \pm 0.21$ & $10.55 \pm 0.35$ & $10.73 \pm 0.46$ & 0.846 \\
\hline 2nd week & $11.73 \pm 0.28$ & $11.41 \pm 0.29$ & $11.37 \pm 0.50$ & 0.758 \\
\hline 4th week & & & & \\
\hline & & & & \\
\hline
\end{tabular}

${ }^{1}$ Results are presented as mean \pm SEM. $n=12$.

${ }^{2} T 1$ means gilts fed one meal per day, $T 2$ means gilts fed two meals per day, and T6 means gilts fed six meals per day.

${ }^{3}$ Different letter ${ }^{\mathrm{a}, \mathrm{b}}$ denotes $P<0.05$. 


\begin{tabular}{|lllll|}
\hline & T1 & T2 & T6 & P-value \\
\hline 6th week & $12.70 \pm 0.32$ & $11.70 \pm 0.60$ & $11.89 \pm 0.59$ & 0.356 \\
\hline 8th week & $13.94 \pm 0.49^{\mathrm{a}}$ & $12.08 \pm 0.48^{\mathrm{ab}}$ & $12.37 \pm 0.58^{\mathrm{b}}$ & 0.035 \\
\hline 10th week & $14.21 \pm 0.44$ & $12.83 \pm 0.64$ & $12.60 \pm 0.64$ & 0.113 \\
\hline 12th week & $15.26 \pm 0.56$ & $14.44 \pm 0.74$ & $13.56 \pm 0.64$ & 0.169 \\
\hline 14th week & $16.36 \pm 0.36$ & $15.72 \pm 0.67$ & $15.08 \pm 0.65$ & 0.215 \\
\hline 1Results are presented as mean \pm SEM. $\mathrm{n}=12$. & & \\
\hline $\begin{array}{l}\text { 2T1 means gilts fed one meal per day, } \mathrm{T} 2 \text { means gilts fed two meals per day, and T6 means gilts fed } \\
\text { six meals per day. }\end{array}$ & & \\
\hline
\end{tabular}

\section{Effects of meal frequency on digestibility of nutrients and nitrogen balance}

Effects of meal frequency on apparent total tract digestibility of energy, EE, CP, and NDF of each gilt are presented in Table 4. There were no effects of meal frequency on the digestibility of DM, CP, EE, ash, and gross energy. Interestingly, digestibility of NDF in T1 pigs were greater compared with the T6 pigs. NDF digestibility in T2 gilts was intermediate and was not affected by meal frequency. As shown in Table 5, meal frequency has no effect on nitrogen digestibility and fecal nitrogen excretion, but the urine excretion in the T6 gilts was greater than T1 gilts. The T1 gilts had increased amount of retained nitrogen and the biological value of nitrogen. 
Table 4

Effects of meal frequency on apparent total tract digestibility of nutrients in gilts $1,2,3$

\begin{tabular}{|c|c|c|c|c|}
\hline Items \% & T1 & T2 & T6 & $P$-value \\
\hline DM & $90.8 \pm 0.013$ & $89.8 \pm 0.003$ & $90.0 \pm 0.004$ & 0.953 \\
\hline $\mathrm{CP}$ & $91.0 \pm 0.013$ & $89.0 \pm 0.013$ & $87.9 \pm 0.023$ & 0.879 \\
\hline $\mathrm{EE}$ & $80.5 \pm 0.027$ & $80.3 \pm 0.016$ & $77.0 \pm 0.020$ & 0.478 \\
\hline Ash & $42.7 \pm 0.048$ & $47.6 \pm 0.019$ & $46.6 \pm 0.020$ & 0.529 \\
\hline NDF & $65.2 \pm 0.038^{a}$ & $57.7 \pm 0.022^{\mathrm{ab}}$ & $54.4 \pm 0.021^{\mathrm{b}}$ & 0.042 \\
\hline Gross energy & $92.6 \pm 0.008$ & $90.8 \pm 0.005$ & $90.7 \pm 0.003$ & 0.065 \\
\hline \multicolumn{5}{|c|}{${ }^{1}$ Results are presented as mean \pm SEM. $n=8$. } \\
\hline \multicolumn{5}{|c|}{$\begin{array}{l}{ }^{2} \mathrm{~T} 1 \text { means gilts fed one meal per day, } \mathrm{T} 2 \text { means gilts fed two meals per day, and } \mathrm{T} 6 \text { means gilts fec } \\
\text { six meals per day. }\end{array}$} \\
\hline \multicolumn{5}{|c|}{${ }^{3}$ Different letter ${ }^{a, b}$ denotes $P<0.05$. } \\
\hline
\end{tabular}


Table 5

Effects of meal frequency on nitrogen balance in gilts $1,2,3$

\begin{tabular}{|c|c|c|c|c|}
\hline Items & T1 & T2 & T6 & $P$-value \\
\hline \multicolumn{5}{|l|}{ Nitrogen balance, $\mathrm{g} / \mathrm{d}$} \\
\hline Intake & 70.04 & 70.04 & 70.04 & 1.00 \\
\hline Fecal excretion & $6.29 \pm 0.93$ & $7.68 \pm 0.88$ & $8.50 \pm 1.59$ & 0.408 \\
\hline Urine excretion & $24.09 \pm 0.99^{a}$ & $32.02 \pm 2.14^{b}$ & $32.26 \pm 3.32^{b}$ & 0.027 \\
\hline Absorbed N & $63.74 \pm 0.93$ & $62.36 \pm 0.88$ & $61.54 \pm 1.59$ & 0.408 \\
\hline Retained N & $39.08 \pm 1.50^{\mathrm{a}}$ & $30.34 \pm 2.55^{b}$ & $29.27 \pm 3.94^{b}$ & 0.040 \\
\hline${ }^{4} \mathrm{~N}$ net utilization, $\%$ & $55.80 \pm 2.14^{a}$ & $43.32 \pm 3.64^{b}$ & $41.80 \pm 5.63^{b}$ & 0.301 \\
\hline N digestibility, \% & $91.01 \pm 1.33$ & $89.04 \pm 1.26$ & $91.75 \pm 1.31$ & 0.189 \\
\hline${ }^{5}$ Retention ratio, $\%$ & $61.31 \pm 2.16^{\mathrm{a}}$ & $48.46 \pm 3.80^{b}$ & $47.20 \pm 5.83^{b}$ & 0.044 \\
\hline \multicolumn{5}{|c|}{${ }^{1}$ Results are presented as mean \pm SEM. $n=8$. } \\
\hline \multicolumn{5}{|c|}{$\begin{array}{l}{ }^{2} \mathrm{~T} 1 \text { means gilts fed one meal per day, } \mathrm{T} 2 \text { means gilts fed two meals per day, and T6 means gilts fed } \\
\text { six meals per day. }\end{array}$} \\
\hline \multicolumn{5}{|c|}{${ }^{3}$ Different letter ${ }^{a, b}$ denotes $P<0.05$. } \\
\hline \multicolumn{5}{|c|}{${ }^{4} \mathrm{~N}$ net utilization, $\%=\mathrm{N}$ retained $/ \mathrm{N}$ intake $\times 100$} \\
\hline${ }^{5}$ Retention ratio, $\%=$ & d/N absorbe & & & \\
\hline
\end{tabular}

\section{Effects of meal frequency on gut microbial metabolites production in gilts}

The feces were collected every 3 hours to detect the concentrations of SCFA acetate, propionate, and butyrate (Fig. 1A-H). Interestingly, we observed time-course changes of SCFAs concentrations in feces at different time points $(P<0.05$, Fig. $1 \mathrm{~A}, \mathrm{C}, \mathrm{E}$ and $\mathrm{G})$. The acetate content in feces of T1 gilts were greater at the times of 11:00, 14:00 and 17:00 compared with gilts in T2 and T6 groups $(P<0.05$, Fig. 1A), but the acetate content in feces T6 gilts was greater than T1 gilts at 23:00 $(P<0.05$, Fig. 1A). The AUC of acetate contents in feces were greater in T1 gilts compared with the other two groups $(P<0.05$, Fig. 1B). The propionate contents in feces were differentially affected by meal frequency at different time points (Fig. 1C). The fecal propionate contents at 02:00, 08:00, 14:00 and 17:00 were different between T1 and T6 groups $(P<0.05$, Fig. 1C). The fecal propionate contents at 14:00 were different between T1 and T2 groups $(P<0.05$, Fig. 1C). The AUC of propionate contents in feces not affected by meal frequency $(P>$ 0.05, Fig. 1D). The fecal butyrate contents were different between T1 and T2 at 14:00 $(P<0.05$, Fig. 1E). 
The AUC of butyrate contents in feces not affected by meal frequency $(P>0.05$, Fig. 1F). The content of total SCFAs in feces, sum of acetate, propionate, and butyrate, were differentially affected by meal frequency at 02:00, 08:00, 11:00, 14:00, 17:00, 20:00 and 23:00 ( $P<0.05$, Fig. 1G). The AUC of total SCFAs contents in feces were greater in T1 gilts compared with the other two groups $(P<0.05$, Fig. $1 \mathrm{H})$.

\section{Effects of meal frequency on blood metabolites in gilts}

To determine whether the meal frequency altered the metabolic state and feed utilization over the course of postprandial phase, the concentrations of serum glucose, insulin, lactate, a-amino nitrogen, and urea before and after a morning meal test were detected and presented in Fig. 2 (A-E). The gilts in T6 group had a greater serum glucose levels than in T1 gilts at -10 min, 0 min, $50 \mathrm{~min}, 75 \mathrm{~min}, 90 \mathrm{~min}, 105 \mathrm{~min}$, $150 \mathrm{~min}$, and $180 \mathrm{~min}$ of meal test $(P<0.05$, Fig. $2 A)$. In T1 gilts, serum glucose concentration increased after $10 \mathrm{~min}$ of meal ingestion and reach a peak at $30 \mathrm{~min}$ postprandially, and then it dropped to values similar to baseline, which is quite different from that of T6 gilts (Fig. 2A). Meal frequency also changed the postprandial serum insulin concentrations, all the gilts in three groups reached the peak at $30 \mathrm{~min}$ after the test meal, while T1 gilts had a greater serum insulin concentration compared with the pigs in T6 group at $0 \mathrm{~min}, 10 \mathrm{~min}, 20 \mathrm{~min}, 30 \mathrm{~min}, 40 \mathrm{~min}, 50 \mathrm{~min}, 60 \mathrm{~min}, 75 \mathrm{~min}$, and $90 \mathrm{~min}$ after a test meal (Fig. 2B, $\mathrm{P}<0.05$ ). Serum lactate concentrations were changed by meal frequency after a test meal in $\mathrm{T} 1$ gilts (time effects: $P<0.05$, Fig. $2 \mathrm{C}$ ), while not observed in T6 gilts. Serum lactate concentrations were differentially affected by meal frequency at $-10 \mathrm{~min}, 0 \mathrm{~min}, 75 \mathrm{~min}, 90 \mathrm{~min}, 105 \mathrm{~min}$, and $120 \mathrm{~min}$ after a test meal $(P<0.05$, Fig. $2 C)$. In T1 and T2 gilts, serum a-amino nitrogen reaches the peak at $30 \mathrm{~min}$ postprandially (time effects: $P<0.05$, Fig. 2D). However, in T6 gilts, serum a-amino nitrogen levels were independent on meal ingestion (time effects: $P>0.05$, Fig. 2D). Except at the peak, the serum concentrations of a-amino nitrogen were differentially altered by meal frequency at $-10 \mathrm{~min}, 0 \mathrm{~min}$, $75 \mathrm{~min}, 90 \mathrm{~min}, 120 \mathrm{~min}, 150 \mathrm{~min}$, and $180 \mathrm{~min}$ after a test meal $(P<0.05$, Fig. 2D). Serum urea concentration did not vary with time after meal ingestion (time effects: $P=0.09$, Fig. 2E). Urea levels were lower in T1 gilts than in T6 gilts $(P<0.05$, Fig. 2E).

\section{Effects of meal frequency on the secretion of luteinizing hormone and ovarian follicular development}

As shown in Table 6, the rate of gilts that reached puberty by age days 180, 200, and 250 in T1 and T6 gilts were $41.67 \%$ versus $8.33 \%, 66.67 \%$ versus $41.67 \%$, and $91.67 \%$ versus $75 \%$, respectively, but the difference was not significant $(P>0.05)$, and the age at puberty, bodyweight at puberty and backfat thickness at puberty were not affected by meal frequency $(P>0.05)$. To further evaluate whether meal frequency has an effect on ovarian follicular development, we investigated the serum reproductive hormone levels on 18th day of the third estrous cycle. The gilts in T1 group exhibited a substantially greater LH concentrations compared to gilts in T2 and T6 groups at different time points on the 18th day of the 3rd estrus cycle $(P<0.05$, Fig. 3A), but there were no marked differences in FSH levels $(P>0.05$, 
Fig. 3B). The $\mathrm{E}_{2}$ concentrations in T1 gilts were greater than in T6 gilts $(P<0.05$, Fig. $3 \mathrm{C})$ on the 18th day of the 3rd estrus cycle.

Table 6

Effects of meal frequency on pubertal onset in gilts ${ }^{1,2,3}$

\begin{tabular}{|c|c|c|c|c|c|c|c|}
\hline \multirow[t]{2}{*}{ Items } & \multirow[t]{2}{*}{$\mathrm{T} 1$} & \multirow[t]{2}{*}{ T2 } & \multirow[t]{2}{*}{ T6 } & \multicolumn{4}{|l|}{$P$-value } \\
\hline & & & & ANOVA & $\begin{array}{l}\text { T1 vs } \\
\text { T2 }\end{array}$ & $\begin{array}{l}\text { T1 vs } \\
\text { T6 }\end{array}$ & $\begin{array}{l}\text { T2 vs } \\
\text { T6 }\end{array}$ \\
\hline Number of gilts & 12 & 12 & 12 & - & - & - & - \\
\hline Age at puberty $(d)$ & $\begin{array}{l}193.6 \pm \\
6.78\end{array}$ & $\begin{array}{l}194.5 \pm \\
5.75\end{array}$ & $\begin{array}{l}199.2 \pm \\
8.74\end{array}$ & 0.843 & - & - & - \\
\hline $\begin{array}{l}{ }^{4} \text { Puberty onset by age } \\
180 \mathrm{~d}(\%)\end{array}$ & $41.67(5)$ & $8.33(2)$ & $8.33(2)$ & - & 0.371 & 0.371 & 1 \\
\hline $\begin{array}{l}\text { Puberty onset by age } \\
200 \mathrm{~d}(\%)\end{array}$ & $66.67(8)$ & $50.00(6)$ & $41.67(5)$ & - & 0.68 & 0.414 & 0.99 \\
\hline $\begin{array}{l}\text { Puberty onset by age } \\
250 \mathrm{~d}(\%)\end{array}$ & $\begin{array}{l}91.67 \\
(11)\end{array}$ & $\begin{array}{l}83.33 \\
(10)\end{array}$ & $75.00(9)$ & - & 0.99 & 0.59 & 0.99 \\
\hline BW at puberty, $\mathrm{kg}$ & $\begin{array}{l}118.1 \pm \\
3.59\end{array}$ & $\begin{array}{l}120.8 \pm \\
4.75\end{array}$ & $\begin{array}{l}123.8 \pm \\
6.33\end{array}$ & 0.229 & - & - & - \\
\hline BF at puberty, mm & $\begin{array}{l}12.9 \pm \\
0.44\end{array}$ & $\begin{array}{l}13.24 \pm \\
0.78\end{array}$ & $\begin{array}{l}14.1 \pm \\
0.69\end{array}$ & 0.283 & - & - & - \\
\hline \multicolumn{8}{|c|}{${ }^{1}$ Results are presented as mean \pm SEM. } \\
\hline \multicolumn{8}{|c|}{$\begin{array}{l}{ }^{2} \mathrm{~T} 1 \text { means gilts fed one meal per day, } \mathrm{T} 2 \text { means gilts fed two meals per day, and T6 means gilts fed } \\
\text { six meals per day. }\end{array}$} \\
\hline \multicolumn{8}{|c|}{${ }^{3}$ Different letter ${ }^{a}, \mathrm{~b}$ denotes $P<0.05$. } \\
\hline
\end{tabular}

The gene expressions of COC were presented in Fig. 3 (D-L). The mRNA levels of ovarian gonadotropin receptors FSHR and $L H C G R$, were greater in T1 and T2 gilts compared with T6 gilts $(P<0.05$, Fig. 3D and $3 \mathrm{E})$. We next evaluated the gene expression levels related to ovarian follicular development, including bone morphogenetic protein 15 (BMP15) and Growth differentiation factor 9 (GDF9). The mRNA expression of BMP15 and GDF9 were elevated by less meal frequency in gilts (Fig. 3F and 3G). The expression levels of steroidogenic enzymes (CYP11a1, cytochrome P450, family 11 , subfamily $A$ polypeptide 1 ; STAR, steroidogenic acute regulatory protein and $3 \beta$-HSD, 3-beta $(\beta)$-hydroxysteroid dehydrogenase) were increased by decreased meal frequency $(P<0.05$, Fig. $3 \mathrm{H}-3 \mathrm{~J})$. No differences in the expressions of CYP17a and CYP19a were affected by meal frequency (Fig. 3K and 3L). 
Effects of meal frequency on the development of follicles of gilts at 3rd estrous were presented in Table 7. The numbers of primordial follicle, and antral follicles with diameter between 1-3 mm, or antral follicles with diameter $\geq 3 \mathrm{~mm}$ were not affected by meal frequency $(P>0.05)$. The number of growing follicles, sum of numbers of primary follicle, secondary follicle, and antral follicle (with diameter below $1 \mathrm{~mm})$, were greater in pigs fed one meal per day compared with gilts fed six meals per day $(P<0.05)$. Compared the T1 gilts with the T6 gilts, decreased meal frequency increased the number of corpora lutea $(P<0.05$, Table 7).

Table 7

Effects of meal frequency on the development of follicles of gilts at 3rd estrous ${ }^{1,2,3}$

\begin{tabular}{|c|c|c|c|c|}
\hline Items & T1 & T2 & T6 & $P$-value \\
\hline \multicolumn{5}{|l|}{${ }^{4} \mathrm{NO}$. of Follicle per $\mathrm{cm}^{2}$} \\
\hline Primordial follicle & $11.80 \pm 1.02$ & $10.97 \pm 0.75$ & $10.77 \pm 1.08$ & 0.732 \\
\hline Growing follicle & $12.37 \pm 0.78^{a}$ & $10.37 \pm 1.04^{\mathrm{ab}}$ & $8.13 \pm 0.79^{b}$ & 0.016 \\
\hline Total follicles & $24.17 \pm 1.38$ & $21.64 \pm 1.39$ & $18.91 \pm 1.49$ & 0.087 \\
\hline \multicolumn{5}{|l|}{${ }^{5}$ NO. of visible Follicle, $n$} \\
\hline Diameter $1 \sim 3 \mathrm{~mm}$ & $29.20 \pm 1.69$ & $27.60 \pm 1.08$ & $28.40 \pm 1.81$ & 0.772 \\
\hline Diameter $\geq 3$ mm & $32.80 \pm 3.88$ & $30.00 \pm 3.74$ & $29 \pm 1.82$ & 0.705 \\
\hline NO. of corpora lutea, $n$ & $28.80 \pm 3.22^{\mathrm{a}}$ & $22.60 \pm 1.12^{\mathrm{ab}}$ & $18.20 \pm 0.66^{\mathrm{b}}$ & 0.048 \\
\hline \multicolumn{5}{|c|}{${ }^{1}$ Results are presented as mean \pm SEM. $n=5$. } \\
\hline \multicolumn{5}{|c|}{$\begin{array}{l}{ }^{2} \mathrm{~T} 1 \text { means gilts fed one meal per day, } \mathrm{T} 2 \text { means gilts fed two meals per day, and } \mathrm{T} 6 \text { means gilts fed } \\
\text { six meals per day. }\end{array}$} \\
\hline \multicolumn{5}{|c|}{${ }^{3}$ Different letter ${ }^{\mathrm{a}, \mathrm{b}}$ denotes $P<0.05$. } \\
\hline \multicolumn{5}{|c|}{$\begin{array}{l}{ }^{4} \text { Growing follicle, sum of numbers of primary follicle, secondary follicle, and antral follicle (with } \\
\text { diameter below } 1 \mathrm{~mm} \text { ) detected by HE staining. }\end{array}$} \\
\hline
\end{tabular}

\section{Discussion}

Reproductive fitness of gilts is tightly linked to metabolic status, and imbalance of metabolism can cause reproductive disorders and even infertility $[3,17]$. A successful cultivation of replacement gilts not only require a sound growth performance, but also a suitable activation of HPG axis to activate the pubertal onset and normal maintenance of estrous cycle [18]. Meal frequency played a critical role on metabolic status in pig, human and rodent [6-8]. Less MF can affect growth, and alleviate high-fat diet-induced lipid 
accumulation and inflammation in adipose tissue in pigs $[12,19]$. In this study, we tested the hypothesis that whether less MF could influence both nutrient utilization and reproductive process of replacement gilts, and the current findings revealed that less meal frequency increased nutrient utilization, promoted the secretion of luteinizing hormones, and improved ovarian follicular development in gilts. To the best of our knowledge, the results of this study offered a novel linkage between dietary pattern and development of peripheral and reproductive tissues, which will provide new insights into the nutritional strategy for replacement gilts.

Currently, the replacement gilts were typically fed ad libitum, in which the gilts may visit the feeders up to 15 times per day [20]. This eating pattern encourages the gilts extending the period of daily nutrient intake and thereby shortening the fasting period [1]. However, growing evidence revealed that this free eating pattern has been associated with a negative effect on growth, inflammation of adipose tissues and systemic health in growing pigs $[12,19]$. In this study, gilts were fed either with one, two, or six meals per day, but the eating windows of 3 hours were allowed for three dietary treatment groups, which eliminate the differences of energy expenditure (such as heat increment) induced by variations of feeding duration. Early results revealed that the gestating gilts or sows fed two or six meals per day during gestation had differential effects of reproductive outcomes [21], and evidence also revealed that growing pigs fed one meals per day, two meals per day, or free access to feed had different nutrient digestibilities and adipose tissue metabolism [22-24]. Based on those researches, the meal frequencies were set at one, two or six meals per day in the present study. In agreement with previous studies [12], pigs fed less MF increased the ADG and the final bodyweight $(P<0.05$, Table 3$)$. In this study, the feed intake was the similar among the three groups, and the increased the body weight observed in T1 gilts suggested that less MF increased nutrient utilization. In the present study, T1 gilts showed a faster glucose clearance with increased serum insulin concentration $(P<0.05$, Fig. 2A and 2B) which agrees with studies in mouse and human $[6,8]$, showing that glucose was removed faster from the circulation when having a limited access to a single meal compared with ad libitum. Glucose is the most important fuel for metabolism, faster glucose clearance suggests a higher glucose utilization. Insulin augments glucose transport in skeletal muscle, adipose tissue, and other tissues, and this is also supported by enhanced body weight gain in gilts fed less meal frequency. In human and rodent, limited MF has beneficial effects on energy homeostasis, which increased energy utilization and decreased lipid accumulation [10, 25]. To our surprise, in this study, less MF had no effects on the backfat thickness in gilts $(P>0.05$, Table 3$)$, which suggested that less MF did not affect the fat deposition in gilts. The mainly reason for this inconsistency may be attributed to the difference of the age of the animals. Both in human and mouse researches, the models are adults which were easy to have greater fat deposition [6-8], while the period of gilts in this study were at growing phase which has a greater lean tissue accretion than adipose tissue before sexual maturity [26, 27]. In this study, gilts fed one meal per day had increased bodyweight gain but had no effect on backfat thickness, which suggested meal frequency influenced the lean deposition. In order to test whether less meal frequency can influence the lean mass metabolism, we tested the nitrogen balance in gilts. Indeed, the T1 gilts had decreased the urine excretion (T1 vs T6: $24.1 \mathrm{~g} / \mathrm{d}$ vs $32.2 \mathrm{~g} / \mathrm{d}$ ), increased

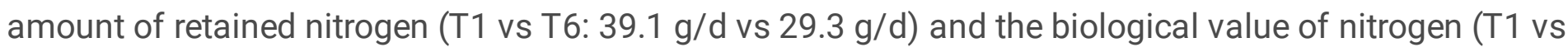


T6: $61.3 \%$ vs $47.2 \%)$. In addition, the gilts fed one meal per day had lower serum a-amino nitrogen and urea levels with time after meal, which suggested less meal frequency improved the nitrogen utilization, and the increased of bodyweight gain was probably attributed to lean mass accretion. Indeed, in neonates' pig, intermittent bolus feeding enhanced muscle protein synthesis to a greater extent than continuous feeding via mTOR pathway [28]. Meanwhile, no effects of meal frequency on the digestibility of DM, CP, gross energy, EE, and ash were observed, but the digestibility of NDF in gilts fed one meal per day were greater compared with gilts fed six meals per day, which suggested that less meal frequency increased the fiber fermentation. Gut microbiota has been recognized as an important factor in regulating host metabolism through SCFAs [10,29, 30], which stimulated us to test the effect of MF on SCFAs production in feces. Our study showed that time-course changes of SCFAs concentrations in feces at different time points were different among different treatment groups $(P<0.05$, Fig. $1 \mathrm{G})$. In agree with that change the interval between meals results in a shift in the gut microbiota composition $[10,11]$. The gilts fed one meal per day showed a cyclic fluctuation in feces SCFAs concentration but not in gilts fed six meals per day $(P<0.05$, Fig. $1 \mathrm{G})$. In this study, T1 feeding regimen increased the acetate and total SCFAs production $(P<0.05$, Fig. $1 \mathrm{~A}$ and $1 \mathrm{G})$. Acetate is utilized for lipogenesis in the liver and as a fuel source once it enters the peripheral circulation [31] and the increased SCFAs production promoted energy availability for both microbiota and host intestine $[32,33]$ that may contribute to the health of gastrointestinal tract and peripheral tissues of host. Taken together, one meal per day increased the nutrient utilization and the growth performance of gilts.

Pubertal onset is the marks of sexual maturation of replacement gilts, which can be affected by the age of growth performance of gilts. In the present study, there was no exhibited marked delay of first observed estrous among the three groups ( $P>0.05$, Table 6$)$, possibly attributed to two reasons. Firstly, the dietary treatment began at the age of $150 \mathrm{~d}$ and bodyweight at $77 \mathrm{~kg}$, which was too late to be affected by dietary treatment at this time. Secondly, although gilts fed one meal per day had a greater bodyweight gain and a greater bodyweight than the gilts fed six meals per day at the 14th week of experiment, the ADG of the gilts fed six meals per day already exceeded the minimum growth rate $(600 \mathrm{~g} / \mathrm{d})$ required for pubertal maturation. The exposure of female to sexually mature male pheromones leads to the initiation of proestrus, including increased hypothalamic secretion of $\mathrm{GnRH}$ and a preovulatory LH surge [2, 34], thus the gonadotropin concentrations were measured the 18th day of the 3rd estrus cycle. In the present study, we found the gilts fed one meal per day exhibited a substantially greater LH concentrations compared to gilts in the other two groups at different time points $(P<0.05, F i g .3 \mathrm{~A})$, but there were no marked differences in FSH levels in gilts $(P>0.05$, Fig. 3B), which suggested less MF promoted GnRH secretion. The concentrations of $\mathrm{E}_{2}$ in circulation were also greater in gilts fed one meal per day (Fig. $3 \mathrm{C}$ ), and this was associated with the genes related to $\mathrm{E}_{2}$ biosynthesis, such as (CYP11a1, STAR, and 3BHSD) $(P<0.05$, Fig. $3 \mathrm{H}-3 \mathrm{~J})$. The gene expressions of GDF9 and BMP15, indicators of oocyte quality [35, 36], were also greater in gilts fed one meal per day and were lower in gilts fed six meals per day $(P<0.05$, Fig. $3 \mathrm{~F}$ and $3 \mathrm{G})$. The release of reproductive hormones is closely associated with ovarian follicular development. In agreement with the increases of $\mathrm{LH}_{\text {and }} \mathrm{E}_{2}$ concentrations, the gilts fed one meal per day had greater number of corpora lutea, an indicator of recently ovulated matured follicles, compared with 
the gilts fed six meals per day $(P<0.05$, Table 7$)$. Interestingly, the gilts fed one meal also had greater number of growing follicles, suggesting that those gilts may have greater number of ovarian reservations. Most studies conducted in human, mouse, and pigs revealed that a larger ovarian pool would resulted in a greater reproductive potential and a longer reproductive span [37, 38]. Given that the reproductive process is controlled by muti-level regulators [18,34], and metabolic status was known to be the important factors influencing the function of hypothalamus-pituitary-gonadal axis $[3,17,39]$. It will be interesting to examine which metabolic signals could mediated the effects of meal frequency on reproductive function of gilts.

\section{Conclusion}

In this study, we have provided evidence that meal frequency exerted profound effects on the nutrient utilization and reproduction function, and gilts fed one meal per day unexpected improves the nutrient utilization and ovarian follicular development. The results of the present study will provide new insights into the nutritional strategy for replacement gilts, as well as the dietary pattern for other mammals, such as human.

\section{Abbreviations}

MF

meal frequency; ADG:Average daily gain; GnRH:gonadotropin releasing-hormone; FSH:follicle-stimulating hormone; LH:Iuteinizing hormone; SCFAs:short-chain fatty acids; AUC:area under a curve; DM:dry matter; EE:ether extract; CP:crude protein; NDF:neutral detergent fiber; COC:cumulus-oocytes complex; FSHR:follicle-stimulating hormone receptor; $L H C G R$ :luteinizing hormone/chorionic gonadotropin receptor; GDF9:Growth differentiation factor 9; BMP15:bone morphogenetic protein 15; CYP11a1:cytochrome P450

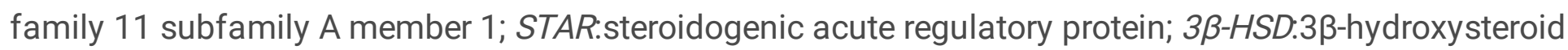
dehydrogenase; CYP17a1:cytochrome P450 family 17 subfamily A member 1; CYP19a1:cytochrome P450 family 19 subfamily A member 1 .

\section{Declarations}

\section{Acknowledgements}

The authors also wish to thank the laboratory staff for their ongoing assistance.

\section{Authors' contributions}

YZ, BF and DW designed and supervised the experiments. LH, LPZ, ZYM, HTL and JL conducted the experiments. LH, LPZ, JL, XMJ, LQC, ZFF, SYX and Yan Lin performed the data measurements and statistical data analysis. LH, ZY and DW wrote and revised the manuscript. All authors have read and approved the final manuscript. 


\section{Funding}

This study was supported by National Key R\&D Program of China (Grant 2018YFD0501005) and National Natural Science Foundation of China, PR China (Grant 31772616). The funding sources had no role in study design, collection, analysis, and interpretation of data, writing of the report, or in the decision to submit the paper for publication.

\section{Conflict of Interest}

All the authors have read and approved the final submitted manuscript and declare that they have no conflict of interest.

\section{Availability of data and materials}

All data generated or analyzed during this study are available from the corresponding author on reasonable request.

\section{Ethics approval}

All experimental procedures followed the regulations of the Animal Care and Use Committee of Sichuan Agricultural University (S20174302), and were in accordance with the National Research Council's Guide for the Care and Use of Laboratory Animals.

\section{References}

1. Kraeling RR, Webel SK. Current strategies for reproductive management of gilts and sows in North America. J Anim Sci Biotechno. 2015;6(1):1-14.

2. Dongsheng $Z$, Yong $Z$, Lianqiang $C$, et al. Nutrient restriction induces failure of reproductive function and molecular changes in hypothalamus-pituitary-gonadal axis in postpubertal gilts. Mol Biol Rep. 2014;41(7):4733-42.

3. Della TS, Rando G, Meda C, et al. Amino acid-dependent activation of liver estrogen receptor alpha integrates metabolic and reproductive functions via IGF-1. Cell Metab. 2011;13(2):205-14.

4. Singhal G, Douris N, Fish AJ, et al. Fibroblast growth factor 21 has no direct role in regulating fertility in female mice. Mol Metab. 2016;5(8):690-8.

5. Moschos S, Chan JL, Mantzoros CS. Leptin and reproduction: a review. Fertil Steril. 2002;77(3):43344.

6. Hatori M, Vollmers C, Zarrinpar A, et al. Time-restricted feeding without reducing caloric intake prevents metabolic diseases in mice fed a high-fat diet. Cell Metab. 2012;15(6):848-60.

7. Chaix A, Zarrinpar A, Miu P, Panda S. Time-restricted feeding is a preventative and therapeutic intervention against diverse nutritional challenges. Cell Metab. 2014;20(6):991-1005. 
8. Sutton EF, Beyl R, Early KS, et al. Early Time-Restricted Feeding Improves Insulin Sensitivity, Blood Pressure, and Oxidative Stress Even without Weight Loss in Men with Prediabetes. Cell Metab. 2018;27(6):1212-21.

9. Cissé YM, Borniger JC, Lemanski E, Nelson RJ. Time-Restricted Feeding Alters the Innate Immune Response to Bacterial Endotoxin. J Immunol. 2018;200(2):681-7.

10. Li G, Xie C, Lu S, et al. Intermittent Fasting Promotes White Adipose Browning and Decreases Obesity by Shaping the GutMicrobiota. Cell Metab. 2017;26(4):672-85.

11. Zarrinpar A, Chaix A, Yooseph S, Panda S. Diet and feeding pattern affect the diurnal dynamics of the gut microbiome. Cell Metab. 2014;20(6):1006-17.

12. Le Naou T, Le Floc'H N, Louveau I, et al. Meal frequency changes the basal and time-course profiles of plasma nutrient concentrations and affects feed efficiency in young growing pigs. J Anim Sci. 2014;92(5):2008-16.

13. Zhou DS, Fang ZF, Wu D, et al. Dietary energy source and feeding levels during the rearing period affect ovarian follicular development and oocyte maturation in gilts. Theriogenology. 2010;74(2):202-11.

14. Zhuo Y, Hua L, Feng B, et al. Fibroblast growth factor 21 coordinates adiponectin to mediate the beneficial effects of low-protein diet on primordial follicle reserve. Ebiomedicine. 2019;41:623-35.

15. Zhuo Y, Cao M, Gong Y, et al. Gut microbial metabolism of dietary fibre protects against high energy feeding induced ovarian follicular atresia in a pig model. Brit J Nutr. 2020:1-12.

16. Hua $L$, Zhuo $Y$, Jiang $D$, et al. Identification of hepatic fibroblast growth factor 21 as a mediator in $17 \beta$-estradiol-induced white adipose tissue browning. Faseb Journal Official Publication of the Federation of American Societies for Experimental Biology. 2018;32(10):5602-11.

17. Sara DT, Nico M, Roberta F, et al. An Essential Role for Liver ERa in Coupling Hepatic Metabolism to the Reproductive Cycle. Cell Rep. 2016;15(2):360-71.

18. Yin W, Gore AC. Neuroendocrine control of reproductive aging: roles of GnRH neurons. Reproduction. 2006;131(3):403-14.

19. Yan H, Cao S, Li Y, et al. Reduced meal frequency alleviates high-fat diet-induced lipid accumulation and inflammation in adipose tissue of pigs under the circumstance of fixed feed allowance. Eur $\mathrm{J}$ Nutr. 2019;59(2):595-608.

20. Estany J, Villalba D, Tibau J, et al. Correlated response to selection for litter size in pigs: I. Growth, fat deposition, and feeding behavior traits. J Anim Sci. 2002;80(10):2556-65.

21. Schneider JD, Tokach MD, Dritz SS, et al. Effects of feeding schedule on body condition, aggressiveness, and reproductive failure in group-housed sows. J Anim Sci. 2007;85(12):3462-9.

22. Chastanet F, Pahm AA, Pedersen C, Stein HH. Effect of feeding schedule on apparent energy and amino acid digestibility by growing pigs. Anim Feed Sci Tech. 2007;132(1-2):94-102.

23. Allee GL, Romsos DR, Leveille GA, Baker DH. Metabolic adaptation induced by meal-eating in the pig. J Nutr. 1972;102(9):1115-22. 
24. Kim KH, Yun HK, Son JE, et al. Intermittent fasting promotes adipose thermogenesis and metabolic homeostasis via VEGF-mediated alternative activation of macrophage. Cell Res. 2017;27(11):130926.

25. Wells JC. Sexual dimorphism of body composition. Best Pract Res CI En. 2007;21(3):415-30.

26. Zachmann M. Assessment of skeletal and sexual maturity: theoretical and practical aspects. Clinical Pediatric Endocrinology. 1993;2(Supple3):15-33.

27. Gazzaneo MC, Suryawan A, Orellana RA, et al. Intermittent bolus feeding has a greater stimulatory effect on protein synthesis in skeletal muscle than continuous feeding in neonatal pigs. $J$ Nutr. 2011;141(12):2152-8.

28. Morrison DJ, Preston T. Formation of short chain fatty acids by the gut microbiota and their impact on human metabolism. Gut microbes. 2016;7(3):189-200.

29. Shimizu H, Ohue-Kitano R, Kimura I. Regulation of host energy metabolism by gut microbiota-derived short-chain fatty acids. Glycative Stress Research. 2019;6(3):181-91.

30. Zhao S, Jang C, Liu J, et al. Dietary fructose feeds hepatic lipogenesis via microbiota-derived acetate. Nature. 2020;579(7800):586-91.

31. Cani PD, Van Hul M, Lefort C, et al. Microbial regulation of organismal energy homeostasis. Nature metabolism. 2019;1(1):34-46.

32. Canfora EE, Meex RC, Venema K, Blaak EE. Gut microbial metabolites in obesity, NAFLD and T2DM. Nat Rev Endocrinol. 2019;15(5):261-73.

33. Skorupskaite K, George JT, Anderson RA. The kisspeptin-GnRH pathway in human reproductive health and disease. Hum Reprod Update. 2014;20(4):485-500.

34. Belli M, Shimasaki S. Molecular aspects and clinical relevance of GDF9 and BMP15 in ovarian function. Vitamins and hormones: Elsevier 2018:317 - 48.

35. Otsuka F, McTavish KJ, Shimasaki S. Integral role of GDF-9 and BMP-15 in ovarian function. Mol Reprod Dev. 2011;78(1):9-21.

36. Ford EA, Beckett EL, Roman SD, et al. Advances in human primordial follicle activation and premature ovarian insufficiency. Reproduction. 2020;159(1):R15-29.

37. Monniaux D, Clément F, Dalbiès-Tran R, et al. The ovarian reserve of primordial follicles and the dynamic reserve of antral growing follicles: what is the link? Biol Reprod. 2014;90(4):85, 1-11.

38. Daftary SS, Gore AC. IGF-1 in the brain as a regulator of reproductive neuroendocrine function. Exp Biol Med. 2005;230(5):292-306.

39. Xu C, Messina A, Somm E, et al. KLB, encoding $\beta$-Klotho, is mutated in patients with congenital hypogonadotropic hypogonadism. Embo Mol Med. 2017;9(10):1379-97.

\section{Figures}


A

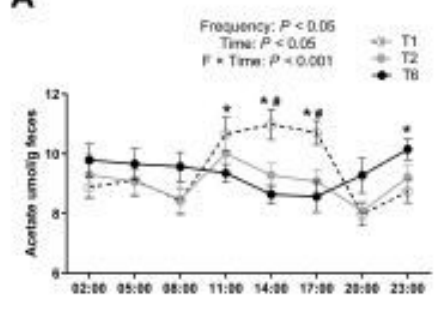

E

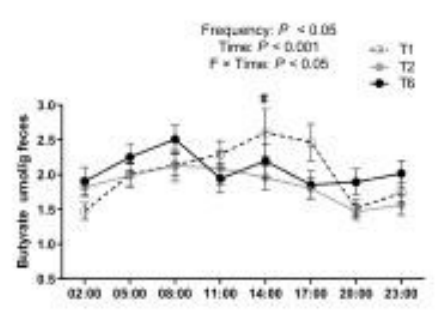

B

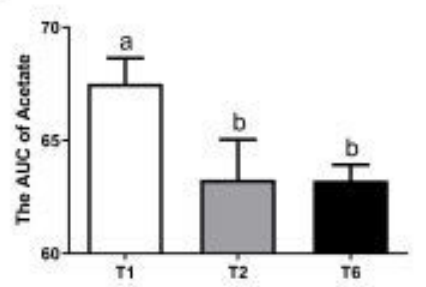

F

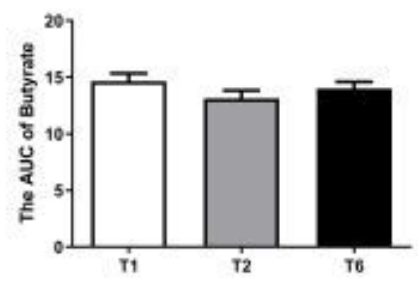

C

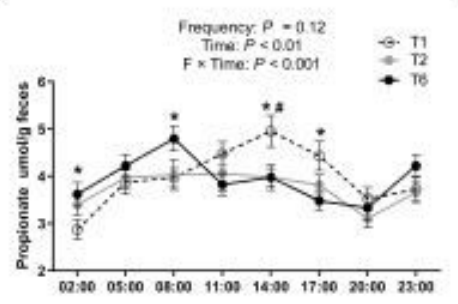

G

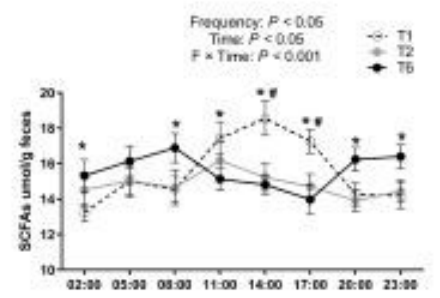

D

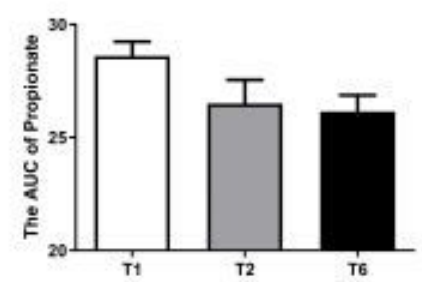

H

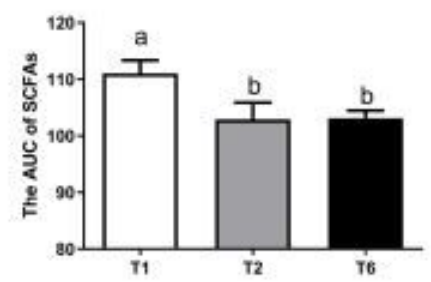

Figure 1

Effects of meal frequency on productions of microbial metabolites in feces of gilts Fresh feces were collected directly by massaging the rectum of each gilt after 13 weeks' treatment every 3 hours of a day. Fecal acetate $(A)$, propionate $(C)$, butyrate $(E)$ and total SCFAs $(G)$ production and the area under curve $(A U C)$ of acetate (B), propionate (D), butyrate $(F)$ and total SCFAs $(H)$. Data are presented as means \pm SEM ( $n=12)$. Fecal SCFAs, acetate, propionate, butyrate production were analyzed by the MIXED procedure with meal frequency, replicate, a repeated statement for sampling time, and the interaction between meal frequency and time as the main effects; The AUC were analyzed by one-way analysis of variance (ANOVA) with Tukey's test for multiple comparisons to determine differences between each group. Values differed significantly at $\mathrm{P}<0.05$, *P < 0.05 (T1 vs T6); \#P < 0.05 (T1 vs T2). Labeled means without a common letter differ, $\mathrm{P}<0.05$. AUC: area under a curve. T1 means gilts fed one meal per day, T2 means gilts fed two meals per day, and T6 means gilts fed six meals per day. 
A

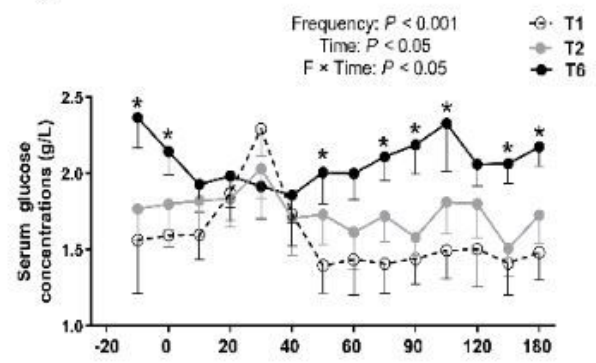

B

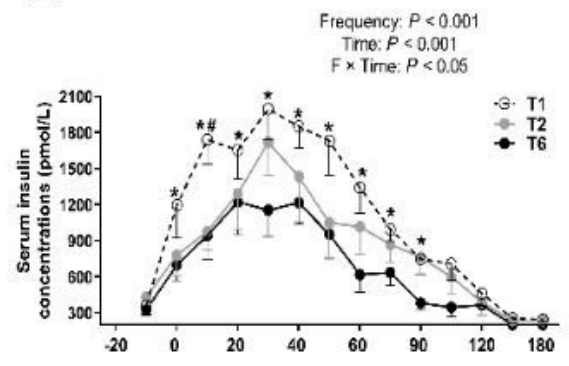

C

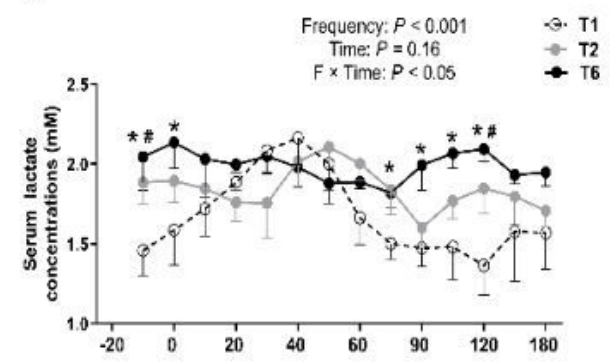

D

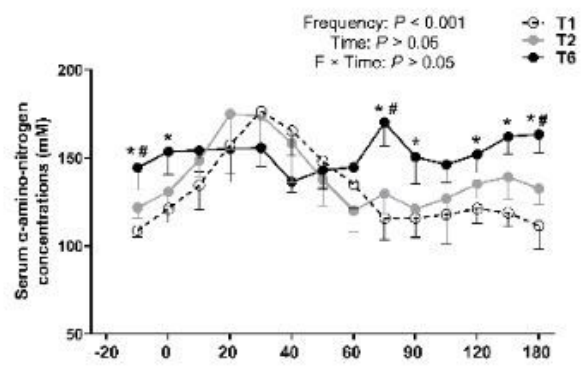

$E$

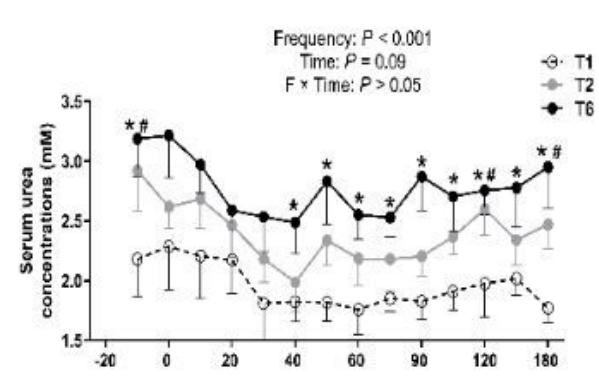

\section{Figure 2}

Effect of meal frequency on metabolic status after a test meal Postprandial changes of serum glucose $(A)$, insulin (B), lactate (C), a-amino-nitrogen (D) and urea (E) concentrations after a test meal during the 12 preceding weeks. Data are presented as means \pm SEM $(n=5-6)$. Data were analyzed by the MIXED procedure with meal frequency, replicate, a repeated statement for sampling time, and the interaction between meal frequency and time as the main effects; Within each time, values differed significantly at $P$ $<0.05$, * $\mathrm{P}<0.05$ (T1 vs T6); \# P< 0.05 (T1 vs T2). T1 means gilts fed one meal per day, T2 means gilts fed two meals per day, and T6 means gilts fed six meals per day. 

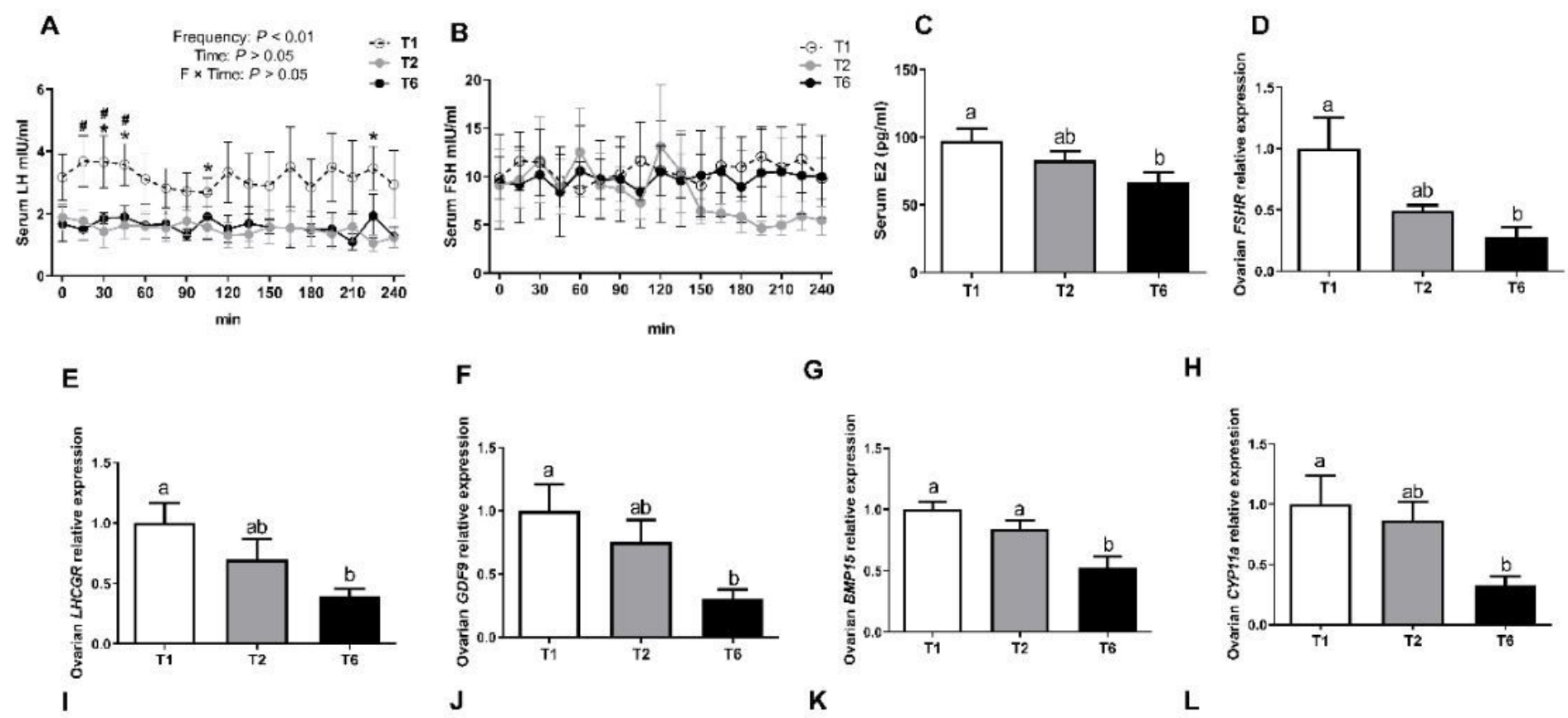

H
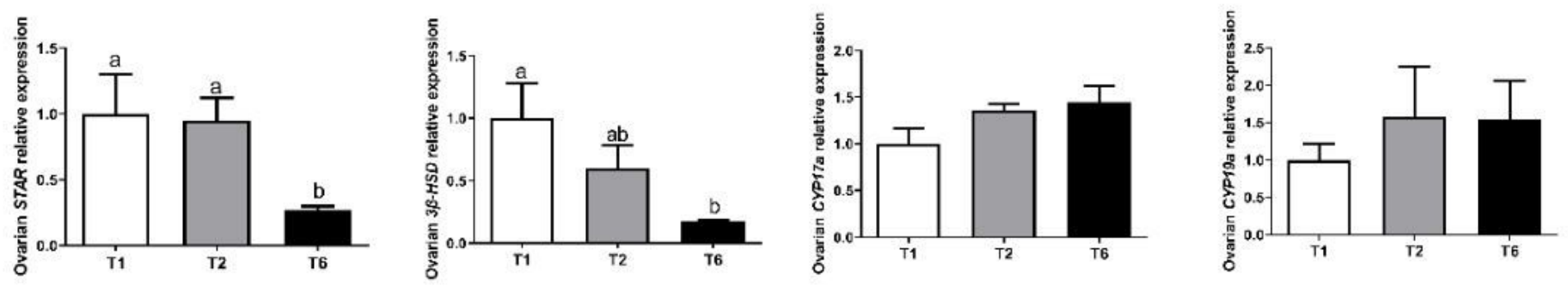

Figure 3

Effects of meal frequency on the development of follicles of gilts at 3rd estrous cycle Serum LH (A) and FSH (B) levels on 18th day of the third estrous cycle every $30 \mathrm{~min}$ for 4 hours. Data are presented as means \pm SEM $(n=6-8)$, and analyzed by the MIXED procedure with meal frequency, replicate, a repeated statement for sampling time, and the interaction between meal frequency and time as the main effects. (C) Serum $17 \beta$-estradiol levels at 19th day of the 3rd estrous cycle. Data are presented as means \pm SEM $(n=6-8)$. The relative gene expression levels of FSHR (D), LHCGR (E), GDF9 (F), BMP15 (G), CYP11a (H), $\operatorname{STAR}(\mathrm{I}), 3 \beta$-HSD $(\mathrm{J})$, CYP17a (K), and CYP19a (L) in cumulus-oocytes complex at 19th day of the 3rd estrous cycle. Data are presented as means \pm SEM $(n=5)$. Data were analyzed by one-way analysis of variance (ANOVA) with Tukey's test for multiple comparisons to determine differences between each group. Values differed significantly at $\mathrm{P}<0.05$, ${ }^{*} \mathrm{P}<0.05$ (T1 vs T6); \# $\mathrm{P}<0.05$ (T1 vs T2). Labeled means without a common letter differ, $P<0.05$. T1 means gilts fed one meal per day, $T 2$ means gilts fed two meals per day, and T6 means gilts fed six meals per day. 